\title{
"Emotional incontinence"
}

I n the movie The Queen, the Tony Blair character berates his staff for their disdain of Her Royal Majesty, Elizabeth II, in the days following the death of Lady Diana.

"That woman has given her whole life in service to her people," says the fictional British prime minister, "and now we line up baying for her blood why? Because she's struggling to lead the world in mourning for a woman who threw everything back in her face, and who seemed, in the last few years, to be committed $24 / 7$ to destroying everything she holds dear."

I like to think scriptwriter Peter Morgan captured the real-life Tony Blair's views because they offer a healthy psychological countervail to all the hoopla marking the Ioth anniversary of Diana's death on Aug. 3I.

In recent weeks we've been inundated with remembrances of the Princess of Wales - from the July concert organized by her sons to a book entitled Lady D that laments how much better the world would be if Diana had lived. Few commentators, it seems, have picked up the implications of Morgan's script: that Diana's elevation to secular sainthood symbolizes the increasing sentimentalization of Western culture.

Sentimentality is an emotional vice of our times. It is not simply a matter of wallowing in what Edmund Burke referred to as "pleasing illusions." Rather, it is a kind of emotional lying to yourself. In his book Sound Sentiments, philosopher David Pugmire describes a sentimentalist as someone who "subordinate[s] truth to desired emotional effect." That is to say, a sentimentalist is less concerned with the actual significance of an object or an event than they are with the emotional impact of that object or event on themselves. In short, "sentimental concern is narcissistic."

Diana's death was unquestionably a defining cultural moment. But the mass grief and her subsequent apotheosis as a cultural icon betray a civilization that has fallen away from traditions of stoical reserve, rational expression and public dignity in times of tragedy.

To be sure, many who stood outside the gates at Buckingham Palace genuinely wanted to pay their respects. Yet who can forget the London parks smothered in teddy bears or the monuments festooned with New Age shrines that jumbled photographs of Diana together with statues of the Virgin Mary, Buddha and Shiva? It was as if an entire society suffered "emotional incontinence," to borrow Theodore Dalrymple's felicitous phrase.

Perhaps the most telling evidence of the sentimental vice was the hostility shown toward the Royal Family for not appearing as mournful as the mob wanted. This being a democratic age, the mob got its wish. The Royal Family had to parade before the teddy bears rather than uphold the public dignity of the monarchy by being allowed to grieve in private.

Such sentimentalism has unhealthy consequences. Sadly, Diana, in her role as The Victim - loveless marriage, lovelorn divorcee, bulimic, desperate devotee of therapy - came to symbolize a society in which self-restraint too readily gives way to self-indulgence, personal responsibility too often surrenders to victimhood and duty is a dirty word.

Increasingly, Western society seems to be driven by sentimentalists. For every ribbon there's a cause, for every donation a victim. Too many believe that when anything bad happens to them, there must be someone else to blame. We grab a lawyer to sue those who trespass on our egos. We turn to politicians who'll assure us we've been victimized. We run to a therapist who'll tell us we aren't lazy or stupid or greedy, but victims of a syndrome or a neurochemical malfunction.

The greatest danger is at the political level. Sentimentalists reject the world as it is, in favour of a wished-for world. And that makes them a threat. A society

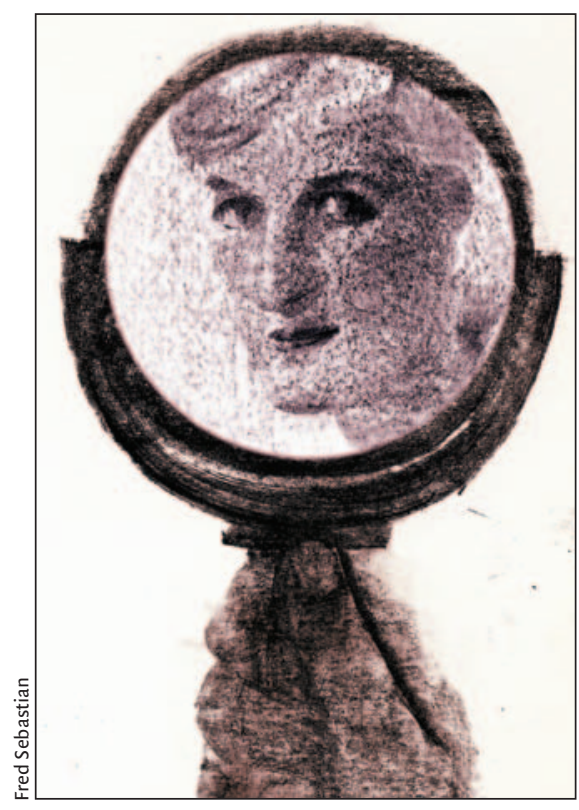

of sentimental citizens no longer has the will to confront its enemies because they are convinced that everyone is fundamentally like them - you know, decent, tolerant, compassionate, broad-minded. Sentimentalists fall into the trap of thinking dialogue and displays of empathy will clear up all misunderstandings between nations. In this way, sentimentalism infects and weakens the institutions - legislatures, churches, the military, etc. - that require reason, restraint and, sometimes, ruthlessness to keep the ship of state afloat.

As some character in The Queen should have said: "Sentimentality threatens to sink everything we hold dear."

\section{Robert Sibley PhD}

Dr. Robert Sibley is a senior writer with the Ottawa Citizen.

We encourage you to post your views on this article at cmaj.ca. Contributors are encouraged to read our online guidelines and send their submission (700 words maximum, French or English language) to salon@cma.ca. 